\title{
Relationship between Strategic Recruitment and Employee Retention in Commercial Banks in Kenya
}

\author{
George Mucai Mbugua ${ }^{1}$, Esther Wangithi Waiganjo ${ }^{1} \&$ Agnes Njeru $^{1}$ \\ ${ }^{1}$ College of Human Resource Development, Jomo Kenyatta University of Agriculture \& Technology, Nairobi, Kenya \\ Correspondence: George Mucai Mbugua, College of Human Resource Development, Jomo Kenyatta University of \\ Agriculture \& Technology, Nairobi, Kenya. E-mail: gemmucai@yahoo.com
}

Received: January 8, 2015

Accepted: January 15, 2015

Online Published: January 17, 2015

doi:10.5430/ijba.v6n1p87

URL: http://dx.doi.org/10.5430/ijba.v6n1p87

\begin{abstract}
The purpose of the study was to examine the relationship between strategic employee recruitment practices and employee retention in commercial banks in Kenya. A survey design was used to gather the information needed to achieve the objectives. Qualitative and quantitative techniques were used. The study was carried out in commercial banks in Kenya which had operating Licenses from the Central bank of Kenya. Questionnaires were used to collect the data. The data was analysed using descriptive statistics mainly percentages and frequency distribution. Correlation and regression analysis were used to test the relationship between the variables. The study established that the organizations practiced strategic recruitment such as the use of associations, psychometric tests, websites, targeting specific professionals, employing head hunting strategies, offer incentives, ranking of potential candidates and utilization of internet and other technologies which influenced the employee recruitment. The study concluded that the strategic employee recruitment influenced the employee retention. The study recommended that the management of all commercial banks should embrace strategic recruitment with the view of retaining their talents and thereby cutting the cost of recruitment and the loss of talents which are valuable to the organizations' competitiveness.
\end{abstract}

Keywords: employee retention human resource management strategic recruitment

\section{Introduction}

Organizations are open systems operating in turbulent environment (Johnson \& Scholes, 2002). They can also be conceived of as complex networks of relationships between workers and managers of different grades within and between teams (Wright 2003). Globalization and its forces have also led to increased awareness and made customers to put pressure for better value products and services thus necessitating development of service quality strategies through the understanding of quality as perceived by the consumers of the services and products. The banking sector in Kenya is governed by the companies Act, the Banking Act, the central bank of Kenya act and the various guidelines issued by the central bank of Kenya (GOK). The central bank of Kenya which falls under the Ministry of finance docket is responsible for formulating and implementing monitoring policy and fostering the liquidity, solvency and proper functioning of the financial system. The banks have come together in Kenya under the Kenya bankers association which serves as a lobby for the banking sector interests. This forms a forum to address issues affecting the members (Central Bank report, 2008).

The commercial banks in Kenya have experienced increased competition for staff over the last few years resulting from increased innovations among the players and new entrants into the market (GOK). A circular from the central bank of Kenya highlights that due to the need for business continuity Management and to ensure that business operations are not adversely affected in the event of a major operational disruption, there is the minimum standards all supervised banking institutions must implement. Most banks in Kenya have embraced online community banking because of the developing interest in buying and selling goods online. Online banking such as Visa have given reason for the bank managers to rethink their strategies in taming the on line market. There has been a stiff competition in Kenyan banking industry in order to serve an informed generation. Most of the banks in Kenya have embraced their strategies in targeting Kenyans in the Diaspora because they are believed to send a lot of money to the banks in Kenya. The strengthening of the Kenyan economy for the last ten years due to the changes in governance has seen a major transformation in the banking industry. Commercial banks have been opened throughout the country to provide financial services. 
According to Wright (2004), (HRM) practices are key agents in building and maintaining trust and they permeate an organization and shape the employment relationships. Employees interpret human resource practices and the trustworthiness of management as indicative of the personalized organization's commitment to them. Perception of an organization's fairness and trustworthiness can be shaped through human resource policies and practices.Within each organization the choices of strategies and policies offer statements of intent and the nature of their implementation and delivery provides tangible evidence of the extent to which management's intentions are genuine and can be trusted (Skinner 2004). Implementation of the various (HR) policies and the consistency of their implementation are important as they provide tangible evidence of the fairness of the organization Armstrong (2002). According to Tzafrir (2005) trust in senior management is more likely to be based on the outcomes of organizational decisions and less on their interpersonal attributes meaning that it is not just the outcomes of organizational decisions that are important but also the way the said decisions are communicated.

Porter (2007) highlighted that a set of high performing human resource practices such as recruitment, training, job design, participation, teamwork, work life balance and rewards were noted as important aspects in attainment of Job fit and this in the long term implies that people experience better fit with the job and the organization when more extensive human resource practices are in place. Storey (2000) says that after organizational entry, in the training, performance appraisal, recognition and reward stages of the Human resource cycle, organizations continue to manage fit levels. Training and development practices are used not only for enhancing skills and knowledge needed to perform well in the job but also for strengthening the desired values. Ashleigh (2007) noted that the safety of the training environment is crucial for team members to learn about each other and develop trust. The supportive environment also fosters positive feelings about working with other team members.

According to Dimba (2010), management of performance within organizations' is widely accepted as being crucial in the achievement of various significant outcomes related to organizational success, including the productivity and quality of employees, their commitment and job satisfaction and consequently forms a key component of human resource management strategy and practice. Performance appraisal is a system that assesses the quality and quantity of an employees work. According to (CIPD, 2005) human resource strategies reflect the philosophy of senior management with regard to the treatment of human resources and address the various activities related to their management, meaning that the HR function supports corporate goals by developing and implementing people management practices which engage employees and encourage them to direct their efforts towards the achievement of organizational goals. Dimba (2010) gives that strategic human resource management practices that best predict high performance are training and development and compensation practices coupled with motivation. Luthans (2005) noted that the strategic human resource management practices for competitive advantage are: information sharing, job design, programmes, job analysis methods, participation programmes, incentive based compensation, benefits, training, grievance, selection and staffing and performance appraisal.

Stavrou (2005) found that the best human resource management practices are: training, share options, profit sharing, group bonus, merit pay, joint HR management bundle, communication( on strategy, finance, change work organization) career, and wider jobs. Ulrich (2005) identified the need for the HR professionals to move away from traditional HR specialisms and create a range of new roles which focus on business outcomes and organisational performance. He identified the need for Human Resource professional to become business and strategic partners who are crucially involved with senior managers and line managers in strategy execution and value delivery and driving change together with being an employee champion and a functional expert. The discussion of strategic human resource management and human resource strategies emphasizes the role of the human resource practitioner as a business partner (CIPD 2005).

\subsection{Statement of the Problem}

According to Abeysekera (2007), employee turnover is a major challenge for organizations but companies implementing effective human resource management practices can reduce the rate of employee turnover and increase in competitiveness due to the fact that by retaining staff an organization it is able to retain its key asset. It is important to critically examine the actions of competitors as it directly or indirectly affects the organization. There are many ways an organization can retain its employees and gain sustained advantage over their competitors among them being the development of comprehensive human resource practices (Narsimha, 2000). According to Hausknecht (2009) there is so much literature information on employee turnover which gives the factors that cause employees to leave an organization but less is known on what compels employees to stay in an organization.

As a result of globalization the whole world have become single markets where companies have crossed their country of origin and opened their operations in other countries and this has created a challenge for organizations in terms of management of human resources (Tiwari 2012). Commercial banks in Kenya face many challenges in 
today's dynamic market place and in a global economy that has become increasingly competitive requiring development of products and services that can satisfy a more demanding customer base and building long term customer trust (Munyoki, 2010). According to Kiptugen (2003) in Kenya commercial Bank, proactive rather than reactive strategies form the basis of strategic planning. Mello (2005) highlights that successful organizations are increasingly realizing that of the number of factors contributing to performance and staff retention, Human resource is the most critical. Commercial banks in Kenya are in very stiff competition for customers and also for staff and these are coupled with the task of retaining the right talent (GOK).

According to Boxall (2003), the big question will which HR policies and practices are more likely to contribute to sustainable competitive advantage and in particular staff retention as organizations go through their life cycle. Purcell (2003) noted that there are two kinds of mature organisations that manage to survive industry development; the one that succeeds in dominating the direction of the industry change and the firm that manages to adopt to the direction of change. Various studies have been carried out on this area, for example Munyoki (2010) researched on the various human resource practices in Commercial banks in Kenya, Kiptugen (2003) carried a study on Human resource practices in commercial banks in Kenya a case study of Kenya commercial bank. Kamoche (2004) carried out a study on staff retention in public universities in Kenya. These studies covered the staff retention in Kenyan universities but did not cover the staff retention in commercial banks in Kenya. This study will investigate the link between the strategic employee recruitment practices and staff retention in Kenyan commercial banks.

\subsection{Hypothesis}

$\mathrm{H}_{0}$ There is no significant relationship between strategic recruitment and employee retention in Kenyan commercial banks

\section{Literature Review}

\subsection{Theoretical Framework}

This theory argues that the organisation should not try to achieve strategic fit with the external environment but aim to maximize its resources to create and dominate future opportunities porter (2008). This approach assumes that the core competencies in the organisation are unique; people are viewed as an investment and not a cost, learning knowledge sharing innovation and experimentation are encouraged and employees are involved in decision making. According to Porter (2008), the resource based approach argues for an exclusive form of 'fit' based on the theory that an organization's resources are the key sources of competitive advantage and this means that organization should not try to achieve strategy fit with the external environment but aim to maximize its resources to create and dominate future opportunities. This approach assumes that the core competencies in the organization are unique. People are viewed as an investment and not a cost, that learning, knowledge sharing, innovation and experimentation are encouraged and that employees are involved in decision making (Bingham 2008).

Armstrong (2008) argues that a resource based approach to strategic human management focuses on satisfying the human capital requirements of the organization. Purcell (2003) suggest that the values and human resource policies of an organization constitutes an important non-imitable resources and this is achieved by ensuring that;- the firm has higher quality people than its competitors, organization learning is encouraged, organization-specific values and a culture exist which bind the organization together (and) gives it focus, and the unique intellectual capital possessed by the business is developed and nurtured. The aim of a resource based approached is to improve resource capability achieving strategic fit between resources and opportunities and obtaining added value from the effective deployment of resources.

\subsection{Strategic Employee Recruitment}

Armstrong (2008) gives the overall aim of recruitment as to obtain at minimum cost the and quality of employees required to satisfy the human resource needs of the company and involves defining requirements (preparation of job description and specifications) and attracting candidates through reviewing and evaluating alternative sources of application inside and outside the company. Boxall (2000) gives a competency based approach to recruitment as that where competencies for a role are delivered and are used as the framework for the selection process. He says that a competency approach to recruitment as person-based rather than job-based. Wright (2004) points out that recruitment and selection are processes concerned with identifying, attracting and securing suitable people to meet and organizational human resource needs. Recruitment is concerned with identifying and attracting suitable candidates.

Porter (2008) says that recruitment and selection provides the conduit for staffing and resourcing the organization. An increasingly competitive and globalised business environment, coupled with need for quality and customer service has enhanced the importance of recruiting and selecting the right people. Boxall and Porcell (2000) highlights that in comparison with the physical tangible assets, an organization have will to determine its competitive advantage. 
Sisson and Storey (2000) gives that recruitment and selection strategy should form part of a wider resourcing strategy linked to organizational goals. Scholes (2002) gives that recruitment and selection is a systematic process and that the psychometric approach to it is closely aligned with that or rational decision making where decision are made on the basis of some kind of assessment about the suitability of individuals who might fill a vacancy.

According to Porter (2008) recruitment and selection is a systematic process which involves the following steps: HR planning, job analysis, job description, application form, advertisement, short listing, selection and finally decision making and offers. The methods of job analysis by Ahmad (2001) includes observation of the person doing the job, getting job holders to record their activities in work diaries, interviewing the job holders, questionnaires/checklists critical incidents and repertory grid techniques. CIPD (2005) notes that the most frequent response to employers to recruitment difficulties was recruiting people who have the potential to grow but don't currently have all that is required.

Employee retention stems from the employment process which comprise of employment processes (recruitment, selection \& placement) predetermines the effectiveness of retention strategy. For employee retention to be successful, it has to be linked positively to the processes and practices of recruitment and the sources from which job candidates are recruited. Recruitment practice and empirical research suggests that employees may differ in their propensity to quit depending on the source from which they are recruited. Two rather different approaches to recruitment identified by Wanous (1975) as cited in Raub and Streit (2006) are the "traditional" approach which suggests that the ultimate goal of recruitment is to attract a maximum number of applicants to the recruiting organisation. In the traditional approach, providing incomplete or even biased information about the job and/ or the organisation may be an acceptable means for reaching this goal.

A review of the Human Resource literature seems to confirm that good retention is about more than what a company does once an employee has been hired and established within an organization. How companies recruit and how they provide orientation in the first days on the job can be of crucial importance to keeping workers over the longer term. Failure to effectively recruit and orient employees may impose significant separation and replacement costs down the road. Jackofsky, (1984) attributes $60 \%$ of undesirable turnover to bad hiring decisions on the part of the employer. "Bad hiring decisions" may cover a number of considerations, including overly hasty selection processes that fail to ensure that the job candidate really has the adequate skills and qualifications to do the job for which she or he is hired.

Good employee retention is in part a result of a good "fit" between a company's workplace culture, its way of doing business and the qualities that it espouses as valuable and the interests, character, and motivations of the individuals that exist within it. In terms of recruitment, companies should therefore put an emphasis on not only evaluating formal qualifications, job-relevant technical ability, etc., but also more general types of qualifications and dispositions on the part of the recruit.

If work in the company involves being part of a highly cohesive team, the company may want to recruit individuals who are interested in and capable of working in such an environment. Employees in some workplaces, particularly the smaller ones, do more than merely work together: they often share similar interests and have a very strong inter-personal rapport, and these in turn help to bind them together as a cohesive whole (Jackofsky, 1984). Indeed, the quality of interpersonal relations may contribute significantly to retention in its own right.

The other approach is the "realistic" approach which suggests that a "realistic job preview" whereby recruiters provide balanced and honest information about both the negative and positive aspects of the job and the organisation is undertaken. The traditional approach was criticised by researchers such as Raub and Streit (2006) who hypothesised that its benefits in terms of attracting a large number of candidates may be more than outweighed by its negative consequences for the selection and retention of those candidates.

According to Raub and Streit (2006), an unrealistic presentation of job-related information may lead to a "rude awakening" when newly hired employees discover the reality of the job. The larger the gap between what has been promised during recruitment and what the employees experience during their first weeks and months on the job, the higher the propensity to quit. The resultant effect is that the new appointees will be frustrated, dissatisfied, and unproductive and in the end they may quit rapidly.

Similarly, Lee (2006) proposes two mediators to recruitment theory as they affect turnover. These are the "realism" with which the candidate comes into the job and the job-fit, i.e. the extent to which the employee feels that the job accords with his/ her personality, ability and so on. Lee (2006) contends that if various recruitment sources can be found to have different realism and job-fit, and these in turn affect turnover, then retention strategies can be crafted around these recruitment techniques. 
Griffeth, Hom, Fink, and Cohen (1997) explain that the recruitment source in which an employee enters a job may impact significantly upon work outcomes, including turnover. Broadly speaking, recruitment sources can be divided into two types, namely internal and external. According to Lee (2006), internal sources denote employees who are sourced from within the organisation while external sources provide employees who come from the outside. External sources include candidates sourced through advertisements in various media, public or private employment agencies, campus recruiting, internet applications, walk-ins, and head-hunted candidates. Internal sources include promotions or demotions (vertical moves), internal job postings (horizontal moves), employee personnel records, intranet advertisements and referrals. Empirical evidence (Lee, 2006) indicates that internal candidates are expected to provide better outcomes than external candidates. In the case of turnover, Lee (2006) proposes that internal candidates are less likely to quit (or will stay for longer period) than externally recruited employees.

Literature by Taylor (1993) as reported in Lee (2006) argues that a realistic approach is proposed to lead to better outcomes for four reasons: Firstly, applicants are better able to deal with the negative aspects of the job in a mental sense. The formation of realistic expectations means dissonance and the resultant dissatisfaction are not experienced. Secondly, candidates will have had time to formulate actual strategies for dealing with negative aspects of the job. Thirdly, the honesty inherent in revealing the less desirable aspects of the job may improve trust between employer and employee, leading to greater loyalty, commitment and retention. Finally, an element of realism enables candidates to decide for themselves whether the job meets their needs and requirements.

Thus, the realistic approach leads to self-deselection of unsuitable candidates out of the recruitment system, probably reducing costs due to early exit, dismissal and so on. Lee (2006) explains that it is generally considered desirable to inject a certain level of realism into the recruitment process. Some recruitment sources are inherently more conducive to realism, as the applicant is given different information depending on where she or he comes from. For example, internal candidates may have more information about the job merely by having had the opportunity to observe their colleagues performing the job. With such job related information at the disposal of job candidates, turnover would be reasonably reduced because prospective employees would have decided whether they want to accept the job or not during recruitment process.

Employee retention should be linked with an effective recruitment and selection process. HR practitioners and recruitment agencies, while recruiting job candidates for their organisations, should consider job previews as an integral part of the recruitment process. Job previews, when honestly conducted, have the potential of reducing early turnover of employees since such employees would have had firsthand knowledge of what the job entails and the conditions of service, particularly the base salary and other financial incentives during the job preview. Though realistic recruitment and job-fit approaches provide an important element for both job satisfaction and employee retention, they must be combined with other motivational variables to form a comprehensive retention strategy that can reduce high turnover rates effectively (Olorunjuwon, 2008).

It is equally important for the individual job candidate to have a fair chance at deciding whether the company is a good fit for him or her. Meyer et al (2003) have emphasized the importance of providing "realistic job previews" to potential employees. These previews provide potential new hires with more than just a cursory glance at a company's operations, providing the candidate with enough information to make a decision about whether it is the right workplace for him or her.

(Jackofsky, 1984) cite the example of a number of companies that simply relate the positives and negatives of the job and the organization in an objective, non-evaluative manner and let the candidate decide whether this is an opportunity that he or she wants to pursue. In the long run, getting real maximizes the fit between candidate and organization. This is not to downplay the importance of other traditional and non-traditional recruitment methods such as structured interviews, multiple and panel interviews, pre-employment testing, biographical data analysis, simulations and work samples. The company must have at its disposal the right tools to enable it to make reasonably accurate evaluations about the type of people it might hire; and there exist a great number of evaluation tools at the employer's disposal.

Many companies place great trust in candidates referred to them by members of their own firm, and some even support this process by awarding bonuses to employees who refer a candidate who eventually gets hired by the company Milman, (2003). While less formal in nature, employee referrals seem to accomplish both of the objectives just described. The employee who provides the referral is able to provide the candidate with a realistic preview of what it's like to work in the company based on personal experience and observation. Meanwhile, because they usually know the person they refer reasonably well, and would be hesitant to refer someone whose performance would reflect badly on them, employees can often provide critical information that resumés, job applications and interviews might not reveal. Including one's employees in helping to evaluate candidates may also be particularly effective with respect to retention 
in workplaces where team-based work is the norm (Milman, (2003). Allowing employees to have a say in whoever they will be working with, and asking for their assistance in evaluating whether that person will be a good fit, may prove helpful in ensuring that the candidate not only has the requisite experience but will also be an effective member of the work team.

\subsection{Employee Retention}

According to Abeysekera (2007), employee turnover is a major challenge for organizations but companies implementing effective human resource management practices can reduce the rate of employee turnover and increase in competitiveness due to the fact that by retaining staff an organization is able to keep its key asset. It is important to critically examine the actions of competitors as it directly or indirectly affects the organization. According to Kok (2003) there are sets of human resource practices which are influenced by the human resource profession and which are referred to as best practice and which if well implemented will ensure retention of staff. According to Chandler (2000), the main issue in human resource research is whether there is a set of policies and practice that represent a set of superior approach to managing people and which are associated with organizational performance and staff retention. There are various factors which affect human resource practices which include both internal and external factors and the same differs from one organization to another (Ozutku 2009). According to Narsimha (2000), there are many ways in which companies can gain a competitive edge or a lasting or sustained advantage over their competitors, among them the development of comprehensive human resource practices.

To gain competitive advantage firms use different competitive strategies and these strategies are more productive when they are systematically linked with human resource management practices meaning that organizations can improve their environment by making efficient choices about human resource practices that consistently support the chosen strategy (Tiwari 2012). According to Capelli (2001), human resource practices enhance organizational performance and there is a clear link between human resource practices, workplace climate and employee retention. He found that those organizations which had implemented more progressive human resource practices and which reported a work place climate that strongly valued employee participation, empowerment and accountability tended to be better performing and hence competitive meaning employees will be happy continuing to work with them.

\section{Methodology}

\subsection{Research Design}

This was a survey research design. A survey design was appropriate for this study because it allows collection of information for both independent and dependent variables using questionnaires (Orodho, 2003). This design allowed the researcher to combine both qualitative and quantitative research approaches. According to Kothari (2009) qualitative approaches provide verbal descriptions rather than numerical descriptions.

\subsection{Population}

The target population in this study was the forty four commercial banks in Kenya which had been given operational License by the Central bank of Kenya. The study population for this study was the heads of human resources in the individual commercial banks in Kenya. Due to manageability of the population, the researcher used census study in which all the elements participated in the study.

\subsection{Data Collection}

The research instrument was a questionnaire consisting of both open- ended and closed- ended type of questions. The closed ended questions were aimed at giving precise information hence minimizing bias. The open ended questions ensured that the respondents were given freedom to express themselves. The questionnaire in this study was divided into six sections with section one giving the identification of the respondent and the job title. The other sections had questions aimed at providing the information on the various areas of this study. Secondary data was collected through review of published literature such as the various bank publications, central bank of Kenya reports and publications and text books. The questionnaires were then delivered by the researcher with the help of the two research assistants to the respondents. The respondents were waited to fill the questionnaire and those who were not in a position to fill them were given a maximum of two weeks to fill them after which the questionnaires were collected.

\subsection{Data Processing and Analysis}

In this study data were analysed using Statistical package for social science (SPSS). All the questionnaires received were referenced and items in the questionnaire coded to make data entry easy. Descriptive statistics were estimated for the various variables. Frequency tables and graphs were made for all the variables. The data reliability was checked using the Cronbachs alpha index. Inferential data analysis was done using Pearson correlation coefficient, regression analysis (enter method) and multiple regression analysis (step wise method). The correlation was used to 
determine the direction of the relationship between the dependent and the independent variables. Multiple regression analysis was used to establish the relationship between the various strategic human resource practices and employee retention. Hypothesis testing using p-value was done because it gave the strength of the decision. According to Mugenda and Mugenda (2003) a significance level of 0.05 is recommended as it represents that results are at $95 \%$ confidence level. The statistical models to be used for analysis was multiple regression (enter method).

$\mathrm{Y}=\beta_{0}+\beta_{1} \mathrm{X}_{1}+€$

Where $\mathrm{Y}$ is the dependent variable employee retention

$\mathrm{B}_{0}$ is the constant

$\mathrm{B}$ is the coefficient of $\mathrm{X}_{1}$

$\mathrm{X}_{1}$ is strategic recruitment

$€$ is the error term

\section{Findings}

\subsection{Reliability Test}

The Cronbach's Alpha values for all the indicators before and after extraction with a factor loadings value of less than 0.4 is presented. Cronbach's Alpha results in the first column were computed using results of all the indicators and the Cronbach's Alpha results in the last column were computed after the reduction of indicators/factors with factor loadings of less than 0.4. The findings of the study show that there were no indicators with less that 0.4 factor loading. All the factor loadings were above the 0.71 which was described by Hair et al. (1998) and Tabachnick and Fidell (2007) as excellent. The researcher therefore retained all the indicators of strategic recruitment as recommended by Hair, Tathan, Anderson and Black (1998) that factors with factor loadings of above 0.4 should be retained for further data analysis. Therefore the Cronbach's alpha result for all the strategic recruitment before and after factor loading remained the same (0.819). The value of the Cronbach's alpha which was above the 0.70 and this corroborated with Zinbarg (2005) that an alpha coefficient of 0.70 or higher indicates that the gathered data is reliable as it has a relatively high internal consistency and can be generalized to reflect opinions of majority of the respondents in the target population.

Table 1. Factor analysis and reliability of strategic recruitment

\begin{tabular}{|c|c|c|c|}
\hline $\begin{array}{l}\text { Cronbach's Alpha } \\
\text { before }\end{array}$ & Indicators & $\begin{array}{l}\text { Factors } \\
\text { loading }\end{array}$ & $\begin{array}{l}\text { Cronbach's } \\
\text { Alpha after }\end{array}$ \\
\hline \multirow[t]{9}{*}{.819} & The organization utilizes psychometric testing & .935 & .819 \\
\hline & $\begin{array}{l}\text { The organization utilizes testing/examination to } \\
\text { evaluate the potential of the target employees }\end{array}$ & .904 & \\
\hline & $\begin{array}{l}\text { The organization offers incentives e.g. bonuses, special } \\
\text { packages to attract potential candidates }\end{array}$ & .901 & \\
\hline & $\begin{array}{l}\text { The organization utilizes internet and other } \\
\text { technologies to attract potential candidates }\end{array}$ & .893 & \\
\hline & $\begin{array}{l}\text { Organization employs head hunting strategies to attract } \\
\text { potential candidates }\end{array}$ & .810 & \\
\hline & $\begin{array}{l}\text { Management has been utilizing associations, } \\
\text { universities, and professional bodies to source for its } \\
\text { employees/talents }\end{array}$ & .793 & \\
\hline & $\begin{array}{l}\text { Organization targets specific professionals to fill a } \\
\text { specific need }\end{array}$ & .774 & \\
\hline & $\begin{array}{l}\text { The organization does ranking of potential candidates } \\
\text { according to job related requirements }\end{array}$ & .746 & \\
\hline & $\begin{array}{l}\text { The organization utilizes websites to target large } \\
\text { audience }\end{array}$ & .736 & \\
\hline
\end{tabular}




\subsection{Strategic Recruitment Practices}

The study sought to determine strategic recruitment practices in the organizations. The findings in Table 2 show that most of the respondents (62.5\%) agreed that the management had utilized associations, universities and professional bodies to source for its employees/talents. The findings also show that about $25 \%$ of the respondents remained neutral to the question. According to $62.5 \%$ of the respondents, the organization used psychometric testing in the recruitment of the staff. However, $15 \%$ of the respondents indicated that the organizations did not use psychometric testing for recruitment of its staff. Majority of the respondents (95\%) indicated that their organization used websites to target large audience in its recruitments. The study findings also revealed that $87.5 \%$ of the respondents indicated that the organizations targeted specific professionals to fill specific needs as a strategic for recruiting talents to the organization. The results show that some $87.5 \%$ of the respondents indicated that the organization used head hunt strategies to attract potential candidates. As to whether the organization did the ranking of potential candidates according to job related requirements, most of the respondent (62.5\%) did not agree nor disagree with the statement meaning they were not sure whether this happened or not. Only $25 \%$ of the respondents indicated that their organizations did the ranking of the candidates according to job related requirements. The respondents were asked to state whether the organizations used internet and other technologies to attract potential candidates. The results show that all the respondents indicated that the organizations used internet and other technologies to attract potential candidates.

Table 2. Strategic recruitment practices

\begin{tabular}{|c|c|c|c|c|c|c|}
\hline & $\begin{array}{l}\text { Strongly } \\
\text { Disagree } \\
(\%)\end{array}$ & $\begin{array}{l}\text { Disagree } \\
(\%)\end{array}$ & $\begin{array}{l}\text { Neither } \\
\text { agree nor } \\
\text { disagree } \\
(\%)\end{array}$ & $\begin{array}{l}\text { Agree } \\
(\%)\end{array}$ & $\begin{array}{l}\text { Strongly } \\
\text { agree } \\
(\%)\end{array}$ & Total \\
\hline $\begin{array}{l}\text { Management has been utilizing associations, } \\
\text { universities, and professional bodies to source } \\
\text { for its employees/talents }\end{array}$ & 2.5 & 10 & 25 & 62.5 & 0 & 100 \\
\hline The organization utilizes psychometric testing & 2.5 & 12.5 & 22.5 & 25 & 37.5 & 100 \\
\hline $\begin{array}{l}\text { The organization utilizes websites to target large } \\
\text { audience }\end{array}$ & 0 & 2.5 & 2.5 & 70 & 25 & 100 \\
\hline $\begin{array}{l}\text { Organization targets specific professionals to fill } \\
\text { a specific need }\end{array}$ & 0 & 0 & 12.5 & 75 & 12.5 & 100 \\
\hline $\begin{array}{l}\text { Organization employs head hunting strategies to } \\
\text { attract potential candidates }\end{array}$ & 0 & 2.5 & 10 & 87.5 & 0 & 100 \\
\hline $\begin{array}{l}\text { The organization utilizes testing/examination to } \\
\text { evaluate the potential of the target employees }\end{array}$ & 2.5 & 10 & 50 & 37.5 & 0 & 100 \\
\hline $\begin{array}{l}\text { The organization offers incentives e.g. bonuses, } \\
\text { special packages to attract potential candidates }\end{array}$ & 0 & 0 & & 62.5 & 37.5 & 100 \\
\hline $\begin{array}{l}\text { The organization does ranking of potential } \\
\text { candidates according to job related requirements }\end{array}$ & 0 & 12.5 & 62.5 & 25 & 0 & 100 \\
\hline $\begin{array}{l}\text { The organization utilizes internet and other } \\
\text { technologies to attract potential candidates }\end{array}$ & 0 & 0 & 0 & 75 & 25 & 100 \\
\hline
\end{tabular}

\subsection{Employee Retention}

The study sought to determine the employee retention in the organizations. The respondents were asked to state the rate of turnover in the organization. The results show that half of the respondents $(50 \%)$ agreed that the rate of turnover in their respective organizations were low. The findings show that $12.5 \%$ of the respondents strongly agreed with the statement. The study sought to determine whether the respondents had the intention of leaving the organizations. The findings of the study show that slightly more than half of the respondents (55\%) had no intention of leaving the organizations. The findings also show that $30 \%$ of the respondents neither agreed nor disagreed with the statement. As to whether their work gives satisfaction to the employees, the findings show that majority of the respondents $(77.5 \%)$ agreed that within the organizations their work gave them satisfaction. The study sought to find 
out how long the respondents intended to stay in the organization. The findings of the study show that $42.5 \%$ agree that they saw future for themselves within this company. The findings show that $40.0 \%$ remained neutral as to whether they were seeing their future in the organization. The results mean that only a section of the respondents see future for themselves in the organization. On whether they were willing to work for the organization for the next five years, the results show that majority of the respondents (77.5\%) agreed that they would be working for their organizations for the next five years. Respondents were asked to state whether if it were possible to start all over again, they would seek employment elsewhere. The findings show that half of the respondents $(50 \%)$ indicated that indeed given chance they would seek job elsewhere if they were to start all over again. The respondents were asked to state whether they would take up a job given an attractive offer. The findings show that majority of the respondents (70\%) agreed that they would take up the offer. The findings mean that the respondents would take up a better opportunity if they came across. The findings however show that $62.5 \%$ of the respondents agreed that the work they did was very important to them. The findings of the study that the employees would leave if they got better offer, agree with Mathis and Jackson (2004) and Khan (2010) who argued that most managers believe that money is the prime reason for leaving one employer for another.

Table 3. Employee retention

\begin{tabular}{|c|c|c|c|c|c|c|}
\hline & $\begin{array}{l}\text { Strongly } \\
\text { Disagree }\end{array}$ & Disagree & $\begin{array}{l}\text { Neither } \\
\text { agree } \\
\text { nor } \\
\text { disagree }\end{array}$ & Agree & $\begin{array}{l}\text { Strongly } \\
\text { agree }\end{array}$ & Total \\
\hline The rate of turnover in the organization is minimal & 0 & 15 & 22.5 & 50 & 12.5 & 100 \\
\hline Have no intention of leaving the organization & 2.5 & 12.5 & 30 & 47.5 & 7.5 & 100 \\
\hline Within this company my work gives me satisfaction. & 2.5 & 5 & 12.5 & 77.5 & 2.5 & 100 \\
\hline $\begin{array}{l}\text { If it were up to me, I will definitely be working for } \\
\text { this company for the next five years. }\end{array}$ & 2.5 & 5 & 12.5 & 77.5 & 2.5 & 100 \\
\hline $\begin{array}{l}\text { If I could start over again, I would choose to work } \\
\text { for another company. }\end{array}$ & 5 & 10 & 35 & 45 & 5 & 100 \\
\hline $\begin{array}{l}\text { If I received an attractive job offer from another } \\
\text { company, I would take the job. }\end{array}$ & 2.5 & 7.5 & 12.5 & 70 & 7.5 & 100 \\
\hline
\end{tabular}
4.4 Whether Strategic Recruitment Practices Influenced Employee Retention

The sought to determine state the extent to which the strategic recruitment practices influenced employee retention in the organizations. The findings of the study in Figure 4.1 show that $30 \%$ of the respondents stated that the strategic recruitment practices influenced employee retention in the organization to a large extent. The findings also show that according to $23 \%$ of the respondents indicated that strategic recruitment practices influenced employee retention to a very large extent while $22 \%$ of the respondents indicated that it influenced to a moderate extent. The findings mean that the strategic recruitment influenced the employee retention.

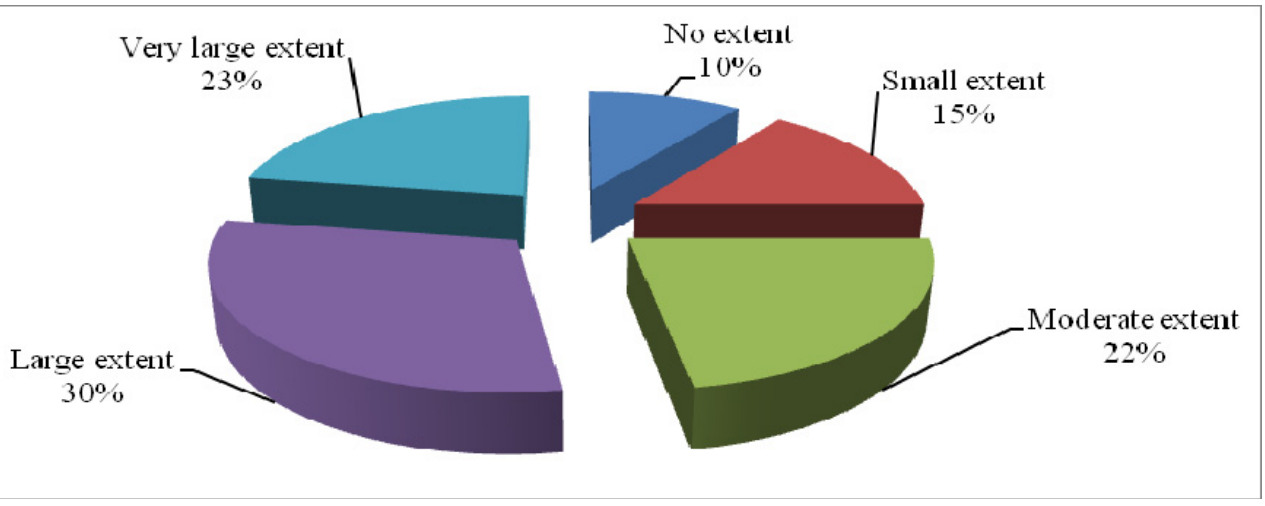

Figure 1. Whether strategic recruitment practices influenced employee retention 


\subsection{Correlation Analysis}

The study conducted correlation analysis to test the strength of association/relationship between the research variables. The findings of the study presented in Table 4 show that strategic recruitment was positively related to the employee retention with a Pearson's Correlation Coefficient of $r=0.056$ and at level of significance of 0.031 , was statistically significant as the $\mathrm{p}$-value is less than 0.05 . This relationship was however very weak.

Table 4. Correlation analysis

\begin{tabular}{llrr}
\hline & & $\begin{array}{c}\text { Strategic } \\
\text { recruitment }\end{array}$ & $\begin{array}{c}\text { Employee } \\
\text { retention }\end{array}$ \\
\hline Strategic recruitment & Pearson Correlation & & 1 \\
& Sig. (2-tailed) & & 0.056 \\
& Pearson Correlation & 0.056 & 0.031 \\
Employee retention & Sig. (2-tailed) & 0.031 & 1 \\
\hline
\end{tabular}

\subsection{Regression Analysis}

The researcher conducted a regression analysis to determine the significance relationship of strategic recruitment against the employee retention. Table 5 shows that the coefficient of determination is 0.570 ; therefore, about $57.0 \%$ of the variation in the employee retention is explained by strategic recruitment. The regression equation appears to be relatively useful for making predictions since the value of $R^{2}$ is slightly more that half.

Table 5. Model summary for strategic recruitment

\begin{tabular}{lllll}
\hline Model & R & R Square & Adjusted R Square & Std. Error of the Estimate \\
\hline 1 & $.755^{\mathrm{a}}$ & .570 & .558 & .601 \\
\hline
\end{tabular}

Table 6 presents the results of the Analysis of Variance (ANOVA) on the strategic recruitment versus the employee retention. The ANOVA results for regression coefficients indicate that the significance of the $F$ is 0.00 which is less than 0.05 . This indicates that the regression model statistically significantly predicts the outcome variable (i.e., it is a good fit for the data). There is therefore a significant relationship between strategic recruitment and the employee retention.

Table 6. ANOVA

\begin{tabular}{|c|c|c|c|c|c|c|}
\hline \multicolumn{2}{|c|}{ Model } & \multirow{2}{*}{$\begin{array}{r}\text { Sum of Squares } \\
18.177\end{array}$} & \multirow[t]{2}{*}{$\mathrm{df}$} & \multirow{2}{*}{$\begin{array}{r}\text { Mean Square } \\
18.177\end{array}$} & \multirow{2}{*}{$\frac{F}{50.334}$} & \multirow{2}{*}{$\frac{\text { Sig. }}{.000^{\mathrm{a}}}$} \\
\hline 1 & Regression & & & & & \\
\hline & Residual & 13.723 & 38 & .361 & & \\
\hline & Total & 31.900 & 39 & & & \\
\hline
\end{tabular}

Predictors: (Constant), Strategic recruitment Dependent Variable: Employee retention

The researcher sought to determine the beta coefficients of strategic recruitment verses the employee retention in the organization. Table 7 shows that there was positive relationship since the coefficient of strategic recruitment is 0.806 which is significantly greater than zero. The t statistics (7.095) was also greater than zero. This demonstrated that the strategic recruitment had a positive influence on the employee retention. With the significant coefficient value of 0.000 which is less than the p-value of 0.05 , we reject the null hypothesis that there is no significant relationship between strategic recruitment and employee retention in commercial banks in Kenya. The researcher therefore accepts the alternative hypothesis that there exists a significant relationship between strategic recruitment and staff retention in commercial banks in Kenya.

Table 7. Coefficients

\begin{tabular}{|c|c|c|c|c|c|c|c|}
\hline \multirow[b]{2}{*}{ Mod } & & \multicolumn{2}{|c|}{ Unstandardized Coefficients } & \multicolumn{2}{|c|}{$\begin{array}{c}\text { Standardized } \\
\text { Coefficients }\end{array}$} & \multirow[b]{2}{*}{$\mathrm{t}$} & \multirow[b]{2}{*}{ Sig. } \\
\hline & & B & Std. Error & Beta & & & \\
\hline 1 & (Constant) & .609 & .412 & & & 1.478 & .148 \\
\hline & $\begin{array}{l}\text { Strategic } \\
\text { recruitment }\end{array}$ & .806 & .114 & & .755 & 7.095 & .000 \\
\hline
\end{tabular}

a. Dependent Variable: Employee retention 


\section{Conclusion}

Based on the findings of the study the study concluded the by practicing strategic recruitment such as the use of use of associations, psychometric tests, websites, targeting specific professionals, employing head hunting strategies, offer incentives, ranking of potential candidates and utilization of internet and other technologies influenced the employee retention. The study therefore concluded that the strategic employee recruitment influenced the employee retention.

\section{Recommendations}

The study recommends that the management of all commercial banks should embrace strategic recruitment with the view of retaining their talents and thereby cutting the cost of recruitment and the loss of talents which are valuable to the organizations' competitiveness.

\section{Limitations of the Study}

The accuracy of findings was limited by the accuracy of statistical tools used for analysis. Some of the top management level employees could not be reached for any comment because of their busy schedules and also obtaining information from the Human Resources personnel was quite challenging because personnel information is not easily given out to employees.

\section{References}

Abeysekera, R. (2007). The impact of human resource practices on marketing executive turnover of leasing companies in Srilanka. Contemporary Management Research, 3(3), 233-252.

Armstrong. (2000). A handbook of human resource management. London: Kogan Page.

Ashleigh, M. (2007). Trust and technologies: implications for organizational work practices, Decision support systems. London: CIPD

Boxall, P., \& Purcell, J. (2003). Strategy and Human Resource Management. London.

Chartered Institute of Personnel and Development. (2005). Recruitment, retention, and turnover: a survey of the UK and Ireland. London: CIPD.

Dimba, B. (2009). The effect of SHRM Practices on Performance of Manufacturing MNCS in Kenya. A Moderating role of employee Cultural orientations. Proceedings of the $10^{\text {th }}$ Annual Conference. IAABD.

Hughes, J. C. (2008). Talent Management; A Strategy for Improving Employee Recruitment, Retention and Management within Hospitality Organizations. Journal of Contemporary Hospitality Management Education.

Kiptugen, E.J. (2003). Strategic responses to a changing competitive environment. Degree of Master of Business Administration (MBA), Faculty of Commerce, University of Nairobi.

Luthans, K.W., \& Sommer, S.M. (2005). The impact of high performance work practices on industry issues outcomes. Journal of Managerial Issues, 17(3), 327-345

Mello, J.A. (2005). Strategic human resource management $\left(2^{\text {nd }}\right.$ ed.). South - western college.

Munyoki, J. (2010). An investigation into the marketing strategies used by commercial banks in managing serve breakdown among SME customer. Some experiences in Kenya. Thesis of University of Nairobi.

Narsimhe, (2000). Knowledge management and business strategies. El-Sayed Abou - Zeid Canada

Porter, M.E. (2008). On Competition, updated and expanded edition. Boston Harvard Business School Publishing.

Samuel, O., \& Chipunta, C. (2009). Employee retention and turnover; using motivational variables as a panacea. African Journal of Business Management, 3(8).

Stavrou, E. (2005). Human resource management as a competitive tool in Europe. Working paper 0414, Henley Management College.

Storey, J. K. (2000). The realities of human resources management. Milton Keynes: Open University Press.

Tzafrir S. S., Harel G. H., Yehuda B., \& Dolan S. L. (2004). The consequences of emerging HRM practices for employee' trust in their managers. Personnel Review, 33(6), 628-647.

Ulrich, D., \& Brockbank, W. (2005). The human resources value proposition. Boston: Harvard Business School Press.

Wright, P., Gardner, T., Moynihan, L., \& Allen, M. (2004). The relationship between HR practices and firm performance: examining casual order. Personal Psychology Journal, 58(2). 